\title{
Resources, Time and Gender: Determinants of Women's Housework in Bahir Dar and nearby Rural Villages, Northwest Ethiopia
}

\author{
Chalachew Getahun*
}

\begin{abstract}
Women's disproportionate engagement in housework and its determinants has been relatively well studied in the developed countries. There is, however, a serious lack of such research for less developed countries. Unless the barriers to women's participation in development efforts are understood and addressed, poverty reduction programs may not succeed. This paper used data from a household survey of 502 married women to analyze determinants of women's hours of housework in light of available theories and employing a multivariate hierarchical linear regression model. Results show that, in line with theory and past research, time availability (measured as women's employment status) and resources or bargaining power (measured as years of schooling and loan receipt status), and gender ideology/display (measured as traditional gender perception/practice) have statistically significant negative associations with a woman's housework time. Similarly, traditional gender perception/practice as a measure of gender ideology/display has the expected positive association with a woman's housework time, despite the weaker statistical significance level. Also, among control variables, housework and non-housework performed by other members, number of young children, and household asset values have the expected associations to women's hours of housework. National strategies aiming at poverty reduction may need to pay more attention to educate women, help them overcome shortage of working capital, and improve employment opportunities since these may also empower women and thereby minimize traditional gender ideology/display and having too many young children.
\end{abstract}

Keywords: Bahir Dar, Ethiopian women, gender ideology, housework/domestic chore, relative resources/bargaining power, time availability, time use DOI: https://dx.doi.org/10.4314/ejossah.v14i2.1

\footnotetext{
*Assistant Professor, Center for Population Studies, College of Development Studies, Addis Ababa University, Email: chalget@gmail.com, Tel: +251913103378, P.O. box 1176/ Addis Ababa
}

This work is licensed to the publisher under the Creative Commons Attribution-NonCommercialNoDerivs License. 


\section{Introduction}

Household labor has usually been conceptualized as the set of unpaid tasks, domestic chores performed to satisfy the needs of family members or to maintain the home and the family's possessions (Coltrane, 2000; Geist, and Ruppanner, 2018; Lachance-Grzela and Bouchard, 2010). Most often, household tasks are classified as (1) routine tasks (those that are on-going, nondiscretionary, very time consuming, and often referred to as women tasks) including laundry, cooking, cleaning; and (2) non-routine tasks (those that are intermittent, can be delayed, are more flexible, less time consuming, and often referred to as male tasks) including household repairs, car maintenance, yardwork and so on (Badr and Acitelli, 2008; Bartley, Blanton and Gilliard, 2005; Batalova and Cohen, 2002; Coltrane, 2000; Geist and Ruppanner, 2018). Most recent housework studies have focused on routine tasks (Batalova and Cohen, 2002; Cunningham, 2007; Pinto and Coltrane, 2008).

Whether it is defined in terms of routine or non-routine activities, housework remains highly gendered, women bearing the lion's share of it (Arora, 2015; Campaña et al., 2017; Canelas and Salazar, 2014; Coltrane, 2000; Fahlen, 2016; Fisher and Robinson, 2011; Folbre, 2006; Gimenez-Nadal and Sevilla, 2012; Lachance-Grzela and Bouchard, 2010; Medeiros, Osorio and Costa, 2007; Ringhofer, 2015). According to the World Bank (2001), there is persistent occupational segregation by gender both in developed and developing countries, with women underrepresented in better-paying formal sector jobs and overrepresented in the unpaid and informal sectors.

This under-representation of female labor market participation, and their disproportionate engagement in unpaid activities has been a major focus of past research (Bardasi and Wodon, 2010; Blackden and Wodon, 2006; Burchardt, 2008; Floro and Miles, 2001; Ilahi, 2000; Gammage, 2010; Ringhofer, 2015). Such studies have increasingly shown men's increasing involvement in housework and the decreasing gender gap over time (Aassve, Fuochi and Mencarini, 2014; Beaujot, 2001; Craig, 2006; Sullivan, Billari and Altintas, 2014). However, there is consensus among most such past research that this downward trend in gender gap is mainly the result of women decreasing their share of unpaid work, rather than men increasing their share (Bartley, Blanton and Gilliard, 2005; Baxter, 2002; Bianchi et al., 2012; Bittman et al., 2003; Coltrane, 2000; Dempsey, 2002; Evertsson and Nermo, 2007; Fahlen, 2016). As such, though declining, these findings suggest that a clear gender pattern still exists even for the developed countries. From these past studies then, the single majority of which are for the developed countries, the fact that there is gendered pattern in housework is very 
clear. However, there is substantial difference in the magnitude of the gendered division of housework and severity of its consequences between developed and developing countries - it is far higher for the latter (Heisig, 2011). This is not surprising given the under developed nature of socioeconomic conditions and the prevalence of deep rooted traditional cultures in most if not all developing countries.

The association between gendered division of housework and poverty has been sufficiently acknowledged. For example, Ilahi (2000) found that poor women do more housework compared to richer women. A typical woman in rural Africa assumes the greatest proportion of housework (food producer/processor, homemaker, caretaker) and only rarely engages in paid work (Arora and Radan, 2013). Ethiopia, too, is a low income, agrarian economy where women are heavily represented in domestic activities since they do not have access to the market system and the wider economy (Arora and Radan, 2013). If gendered division of housework has adverse consequences on the wellbeing of women and households for the developed countries, it must have even more severe consequences for the developing countries, suggesting the need for more context specific research. In developing countries where women take disproportionate share and longer hours of housework than men, these activities often prevent them from participating in paid work (could be formal or informal), and girls from attending school (World Bank, 2001). When women have limited ability to earn income independently, they have less relative bargaining and decision making power in the household since they do the housework at the expense of income generating activities, and when girls cannot attend school, their future capabilities suffer, with implications for their family's welfare (World Bank, 2001). This raises questions about how women's primary responsibility for household work affects their own and their families' welfare. Reducing the burden of housework for women in poor countries have potential benefits for their health, for household income and wellbeing, and for girls' schooling (World Bank, 2001). Explanation of what determines women's participation in housework and hours worked, which differs depending on context specific circumstances between and within countries, is thus of vital importance.

Since recent decades, women's empowerment has become one of the key areas of emphasis by global development initiatives such as the MDGs and more so by its successor, the SGDs. This has been more so for Ethiopia, where, as part of its country initiatives on SDG-1 (Ending Poverty in All its Forms), the UN Women Ethiopia program is supporting the Ethiopian government to help women (rural) secure their livelihoods and accelerate their economic empowerment (Women and Sustainable Development Goals). From development policy point of 
view in the Ethiopian context, this is especially important given the government's emphasis on women's economic empowerment set out by the various national development plans (past and present) including the current Growth and Transformation Plan. The development plans identify, among other things, women labor market participation as critical for achieving the planned development through women empowerment. So far, the government has implemented three fiveyear national development plans and a fourth plan is being implemented. Despite continued claims of economic growth by the government for the last one and a half decade, this is debated among the majority of people including academics, opposition parties, and the general public. Especially, its effect on the lives of women and the majority of poor households is highly contested. Although the prime objective of the national development plans, especially that of the Growth and Transformation Plan is to accelerate Ethiopia's structural transformation, the country is yet in the early stage of the demographic transition (Ringheim Teller and Sines, 2009), and about $80 \%$ of the population is employed by agriculture which is still traditional and highly subsistent. The percentage of women working in productive activities is low. For example, the 2005 Ethiopian DHS (Central Statistical Agency of Ethiopia and ORC Macro, 2005) shows female participation rate to be $39.6 \%$ and $26.6 \%$ respectively for women in the urban and rural subsamples by the time of the survey. By contrast, the proportion of women working in housework is the largest (Central Statistical Agency of Ethiopia, 2014).

Local studies analyzing gendered practices as relating to the various aspects of life (social, economic/resources, political, institutional, etc) are abundant in the literature. However, there are only a few studies which specifically dealt with gendered division of labor or time use. One such study is by Wessen (2008) who examined the prevalence of gendered division of labor among the Majangir ethnic groups of Southwestern Ethiopia. He found the gendered division of labor to be still pervasive despite changes in their socioeconomic conditions. However, Wessen's study did not include proper analysis of what determines such division of labor. Hirut (2010) studied factors influencing a woman's labor allocation to a livestock fattening enterprise funded from a loan obtained from microfinance institutions in Amhara and SNNP regions. The study indicated that being older, being in a polygamous marriage, and longer duration of membership in the credit program increases women's relative labor contribution to the enterprises, compared to that of men. However, apart from only five predictors considered, this study focused on intra-household decision making power in labor allocation to income generating activities rather than those factors that determine her housework. As is noted above and elsewhere in the paper, it is possible for women 
to increase their time for paid work but still be doing the largest share of housework, thus resulting in their being overburdened and time poor. Guday (2005) noted that men in rural areas of Amhara Region are disproportionately engaged in productive agricultural activities whereas women are largely engaged in home based reproductive activities. The author also noted that while women help their husbands in the farms, in return, they do not receive husbands' help in housework, an activity culturally labeled as women's work (Guday, 2005, p. 112). Again, Guday's study did not include proper analysis of what determines such gendered division of labor. Solomon and Kimmel (2009) observed the effect of fertility on a labor market participation of urban women, and Chalachew (2013) examined the effect of fertility on urban and rural women's hours of productive work participation. Arora and Radan (2013) analyzed the gendered division of labor (time use) employing a household accounting matrix (HAM) instead of analyzing its determinants. In a topic directly relevant to the present paper, Asnakech and Chalachew (2015) studied demographic and socioeconomic determinants of time use for household activities among adult members of sample households in Addis Ababa. However, apart from lack of focus on women (since time use of all adult individuals was considered), no relevant theories were used to guide the analysis. Therefore, many of these local studies focused on analysis of prevalence of gendered division of labor, while some of them focused on analysis of causal links between fertility and labor market participation of women, and none of them properly analyzed the determinants of women's time use for housework.

Apart from its implication for the theoretical discussion regarding women's time use for housework (discussed in the next section), women's disproportionate representation in the unpaid housework and their under-representation in paid work may have important repercussions to the achievement of the much hoped-for growth and transformation plan (GTP II). As noted, the development plans emphasized the importance of increasing women's economic opportunities, but past outcomes were not as expected. An increase in women's labor market participation requires a decrease in housework time since time is a limited resource. In turn, this requires knowledge of what factors determine this time allocation for housework, so as to inform gender sensitive policy making.

This paper uses a household sample survey of 502 married women in Bahir Dar City and rural villages of two nearby districts to analyze the determinants of maternal hours for domestic work, discussed in the theoretical literature below. 


\section{Housework Theories}

The literature on allocation of housework time is dominated by three theoretical perspectives (Arrighi and Maume, 2000; Bianchi et al., 2000; Coltrane, 2000; Davis et al., 2007; Fahlen, 2016; Fuwa, 2004; Greenstein, 2000; Lachance-Grzela and Bouchard, 2010; Pinto and Coltrane, 2008): time availability, relative resources and gender ideology. The first two micro theories are economic explanations (Coltrane, 2000; Fahlen, 2016; Parkman, 2004; Pinto and Coltrane, 2008), since, in general, they are based on rational choice assumptions and motivated by utility maximization objectives, whereas the gender ideology has roots in sociology (Parkman, 2004). While there are also macro-level perspectives (Davis et al., 2007; Fuwa, 2004; Lachance-Grzela and Bouchard, 2010), these three are micro-level theories. For the purpose of this paper, we limit discussion to the micro theories only.

\section{Time availability}

One of the major hypothesis posits that housework time allocated depends on the amount of time spent in paid work (Arrighi and Maume, 2000; Davis et al., 2007; Fuwa, 2004; Geist and Ruppanner, 2018; Gough and Killewald, 2010; LachanceGrzela and Bouchard, 2010), so that members share household tasks according to the time available to each of them (Lachance-Grzela and Bouchard, 2010). Measuring this variable by employment status, history and/or hours worked, past research in general shows that individuals who do more paid work spend less time on housework (Artis and Pavalko, 2003; Bianchi et al., 2000; Bianchi et al., 2012; Ciabattari, 2004; Cunningham, 2007; Fuwa, 2004; Geist and Ruppanner, 2018; Gershuny, Bittman and Brice, 2005; Gough and Killewald, 2010; Greenstein 2000; Lachance-Grzela and Bouchard, 2010; Pinto and Coltrane, 2008). A related concept to this perspective is comparative advantage which posits that if one member of the household has a comparative advantage in the labor market, say, higher earning, he/she should specialize in labor market production, and the other members should specialize in household production (Fuwa, 2004). In line with economic theory, this implies a rational household's lack of motivation to allocate a member's time to housework if she/he has a comparative advantage in the labor market (Fuwa, 2004). Because women's increased presence in the paid work limits their household time, the need for increase in housework share by their partners has become a major topic of research in the last decade (Robinson and Hunter, 2008). For a married woman, this means that her housework time falls with an increase in her paid work time and rises with an increase in her husband's market time. In testing this specific hypothesis, many studies find a positive relationship 
between wives' hours in market work and husbands' housework (Bianchi et al., 2000; Cunningham, 2007; Fuwa, 2004). In general, past studies have found men's increased participation and hours worked in housework following women's shift from housework to market work, but the magnitude of men's involvement is not matching with that of women's (Baxter, 2002; Bianchi et al., 2012; Bittman et al., 2003; Bartley, Blanton and Gilliard, 2005; Craig, 2006; Dempsey, 2003; Fahlen, 2016; Evertsson and Nermo, 2004; Lincoln, 2008).

However, this perspective is gender neutral in that it does not consider the ways in which gender-specific norms of behavior may mediate the relationship between market work hours and housework hours (Fahlen, 2016; Geist and Ruppanner, 2018; Gough and Killewald, 2010). In addition, this perspective does not adequately address causality, leaving questions of whether women with high family demands work from home to incorporate domestic and paid work, or whether working from home makes women more vulnerable to increased domestic chores (Fahlen, 2016; Geist and Ruppanner, 2018).

\section{Relative Resources/Bargaining}

The relative resources perspective hypothesizes that a partner's own resources, such as earnings, education, and occupational prestige offer decision making or bargaining power to the partner (Arrighi and Maume, 2000; Coltrane, 2000; Davis et al., 2007; Fahlen, 2016; Fuwa, 2004; Geist and Ruppanner, 2018; Pinto and Coltrane, 2008). A key assumption of this theory is that economic resources including education serve as a proxy for bargaining power, where an individual with more such resources will be able to bargain out of housework (Arrighi and Maume, 2000; Fuwa, 2004; Lachance-Grzela and Bouchard, 2010), whereas the partner with less such resources is expected to contribute more housework to compensate for the deficit (Geist and Ruppanner, 2018). This perspective, therefore, views housework as an outcome of negotiation between household members who own key resources to strike the best deal based on self-interest (Coltrane, 2000).

In general, the hypothesis is empirically confirmed (Bianchi et al., 2000; Cunningham, 2007; Davis and Greenstein, 2004; Evertsson and Nermo, 2004; Fuwa, 2004; Parkman, 2004; Pinto and Coltrane, 2008). However, other studies (e. g. Aassve, Fuochi, and Mencarini, 2014; Bittman et al., 2003; Davis and Greenstein, 2004; Greenstein, 2000; Killewald and Gough, 2010; Evertsson and Nermo, 2007; Gupta, 2007) doubted the validity of this hypothesis arguing that empirical studies did not find men and women with similar relative resources to have gender equality of housework. Similarly, a number of scholars debate the 
linear relationship between earning differentials among partners and the allocation of housework (Bittman et al., 2003; Greenstein, 2000). The hypothesis is also criticized from theoretical grounds. Feminists have challenged the perspective more broadly for its rational choice roots in identifying power, patriarchy, and hegemonic norms as key determinants to women's power (Lundberg \& Pollak, 1993). Similarly, Coltrane (2000) remarks that this hypothesis is a result of the neoclassical economic theory of human capital investment and its new household economics variant which assumes overall utility maximization to be the main motive behind the given allocation of time for housework or the labor market among men and women. In addition, the perspective's concept of power is to a great extent confined to the status of spouses and does not adequately consider more multifaceted family structures, cross-generation families or families with coresidential adult children (Geist and Ruppanner, 2018).

\section{Gender Ideology/Doing Gender/Gender Display}

While slight differences between gender ideology and doing gender/gender display in the literature are acknowledged, in general, this perspective posits that individuals are socialized into male or female gender roles. It argues that women remain disproportionately responsible for the housework solely because of their gender instead of time availability or lack of economic resources (Arrighi and Maume, 2000; Geist and Ruppanner, 2018; Lachance-Grzela and Bouchard, 2010). Women may do more housework because it allows them to act in harmony with their feminine gender identities, whereas men may resist doing more housework to defend and buttress their masculine identities as men (Arrighi and Maume, 2000; Bianchi et al. 2000; Erickson 2005). Research has consistently shown prevalence of persistent views regarding how women and men are expected to act (Arrighi and Maume, 2000; Cunningham, 2001; Davis et al., 2007; Geist and Ruppanner, 2018; Fahlen, 2016; Fuwa, 2004). In agreement with this line of reasoning, Bianchi et al. (2000), for example, argued that women become more at ease with housework because, for example, cleaning the home is a sign of women's competence as a wife and mother, but not men's competence as a husband and father. The gender perspective is a useful tool to explain why women do still more housework when their market work hours is equal to or even higher than that of men (Fahlen, 2016), an explanation which the first two hypotheses cannot offer. This is especially, intuitively the case in most subsistent economies and culturally conservative societies such as Ethiopia. Empirically, research generally confirmed the hypothesis despite variations in how the concept was measured (Lachance-Grzela and Bouchard, 2010). Studies (e.g. Fahlen, 2016) have shown that women who hold more egalitarian attitudes towards gender are less likely than women with 
traditional attitudes to report performing all of the housework. Critics (e.g. Geist and Ruppanner, 2018), however, argue that, although gender-display theory identifies how expectations of gender roles structure behavior, its application beyond heterosexual couples is limited both theoretically and empirically.

In summary, review of existing research (e.g. Coltrane, 2000; Geist and Ruppanner, 2018; Lachance-Grzela and Bouchard, 2010) conclude that, overall, the literature reveals that the distribution of household labor is influenced by multiple forces. It shows that all the three micro-theories prove to be important predictors of the gap between men's and women's housework, but none of them yet offers a clear explanation of why women still do the bulk of housework even when they display the personal characteristics that favor a more egalitarian division of household labor. Lachance-Grzela and Bouchard (2010) then suggested employing a combination of these perspectives since the decisions leading to household tasks sharing involves a complex process these theories are also complementary rather than competing to explain spousal housework decisions (Parkman, 2004). They also suggested not just for consideration of macro-theories, but also for cross-level (micro-macro) interactions. Whereas, Geist and Ruppanner (2018) concluded that existing theoretical approaches to housework are narrow in scope and are far short of explaining the various motivations behind women's housework, especially for contemporary families and gender relations. They then suggest several extensions for each of the theories. Further, these problems can be more complicated by context-specific circumstances. In this regard, LachanceGrzela and Bouchard noted "It appears quite clear that we need to continue studying individuals within their ... social context if we wish to arrive at a thorough understanding of the persistent gendered division of household labor and what could change it" (Lachance-Grzela and Bouchard, 2010, p. 778; see also Heisig 2011 for a similar note).

\section{This paper}

In response to Lachance-Grzela and Bouchard's (2010) call for use of a combination of micro perspectives and more appropriate socioeconomic contexts, the present paper tests whether and the extent to which each theory determines women's housework in the Ethiopian context. However, in considering context, the present paper differs from most past research as follows: First, a review of work by Lachance-Grzela and Bouchard (2010) shows that, while only few past studies included childcare within the concept of housework (see e.g., Badr and Acitelli, 2008), most have excluded it (see e.g. Bartley, Blanton and Gilliard, 2005; Davis et al., 2007; Fahlen, 2016; Fuwa and Cohen, 2007). Among the reasons for 
its exclusion is the difference in the utility associated with childcare and housework (Deding and Lausten, 2006), and the difference in their nature and predictors (Lachance-Grzela and Bouchard, 2010). This appears reasonable for the developed countries, where, for example, there are formal childcare services and clear separation between childcare and other activities. In the Ethiopian context the poor, subsistent economy and traditional society mean that childcare is inseparable not only from housework but also even from most market work, especially, in the informal sector (see e.g. Chalachew, 2017). Housework is accomplished as a joint task, where one person takes care of the housework and manages children at the same time. In some cases, especially in rural contexts, children not only often do care for themselves, but also are required to do the housework as well. So, childcare is treated as part and parcel of housework in the present paper. Second, most research conducted in the context of economically developed and socially egalitarian societies estimated separate models for men and women. However, as is discussed in the background, the fact that women are doing more housework compared to men, and that men are increasingly involved in housework has been consistently confirmed by past research. Given that women's housework time is still significantly higher (though declining), and given the absence of research on the Ethiopian context, I preferred focusing on factors determining women's housework time alone (future studies can model men's housework time with women's). In doing so, I added men's, more adult children's and other members' housework contribution together (I also did the same for their non-housework contributions). In less developed, traditional societies including Ethiopia, a woman's time available for housework is expected to be substantially influenced not only by work contribution of own children, as is reflected, for instance, in the high prevalence of child labor, but also by the contribution of other members living with the family in an extended family structure, characteristic of developing countries.

\section{Data and Method \\ Sampling and Data Collection}

A cross sectional quantitative data set was used to examine determinants of time use for household activities. Samples were drawn from four urban kebeles and two rural villages. The four urban kebeles were selected from Bahir Dar, the Amhara regional state capital, and two rural villages were selected from two different districts located near but not physically contiguous to the city. For the urban subsample, two kebeles dominated by informal, sub-standard housing conditions and two other kebeles dominated by formal, standard housing conditions were selected 
randomly after stratifying the kebeles by the physical qualities of housing units. The rural households were randomly selected from one kebele drawn from each of the two districts.

Sample households were randomly selected from each kebele and village, based on proportion to size of the target household units in each kebele and village. Samples were selected in two different time periods. First, a sample of 257 women were interviewed in October 2010, and then with the view to increasing the earlier sample size, additional 245 women residing in the same place as the previous sample were interviewed in 2013, giving a total sample size of 502. While, from a theoretical point of view, the time lapse may have an important effect on the outcome variables, the author assumed the effect to be minimal, given the specific context of the study region where there was no any observed significant demographic, socioeconomic, and institutional changes in policy and practice. In terms of selection criteria, married women with children were targeted. Previous research focused on looking at whether time use differed by marital status and by whether they have children. In this paper, the intention is to see how women's hours of work in domestic chores may still vary even among married women, some of which could be explained by husband related characteristics. On top of that, review of work by Coltrane (2000) shows that marriage increases women's housework. Similarly, a study by University of Michigan (2008) shows that having a husband creates an extra seven hours of housework for women. As such, married women compared to unmarried or single women are disadvantaged since they sacrifice their own economic, cultural, psychological and personal development and wellbeing for the sake of their family chores (Coltrane, 2000; Lahiri-Dutt and Sil, 2014). The choice of women with children is rather pragmatic since, in the author's view, it is the number of children instead of not having a child at all which is not only realistic but also desirable from policy point of view. On top of that, children need to be considered given, as is noted in section 2, that childcare is included within the housework definition as the dependent variable.

Data were collected through a questionnaire in a face-to-face interview. The questionnaire was pilot-tested, and necessary revisions made. Respondents were asked to provide an approximate number of hours spent on each of the activities listed, over the last seven days before the survey date. A major problem associated to time use survey is a recall error. Although, as a general consensus, a recall of more than two days should not be asked, many studies ask for the previous week, month, or sometimes even for a year (see. e.g. Masuda et al., 2014; Ilahi, 2000; Coltrane, 2000 and the references therein). This means, a recall of activities over the last seven days does not appear to be a serious problem. To the 
contrary, it can be argued that collecting data for only the past day or two can be equally problematic if not more problematic. In this regard, Arora and Rada (2013) noted that the survey instrument for the Ethiopian Rural Household Survey asked time use only for the previous day, and, as a result, they had to drop many households from analysis since not all households in the sample undertook farm work every day. For the present paper, the questionnaire raised questions on a range of demographic and socioeconomic variables and women's time allocation for household domestic work, over a period of the last seven days. It also asked a few questions on gender.

\section{Measurement and Data Analysis}

The outcome measure (dependent variable) for the study is women's time spent in household activities (measured in hours per day, converted later on to minutes per day for the multi-variate analysis). As is discussed in section 2, housework in this paper includes activities such as cooking/food processing; cleaning and washing; local shopping for consumption; childcare and care of other members, and doing other reproductive routines for the household. All housework time was added together. Time spent in household activities was regressed on three key variables of interest. These were a woman's employment status (employed $=1$; otherwise $=0$ ) as time availability indicator for non-housework (i.e. for market or own consumption); a woman's years of schooling (in years) and a woman's loan receipt status (received $=1$; otherwise $=0$ ) as indicators of resources/bargaining power available to a woman; and a measure of indicators of traditional gender ideology or display (traditional $=1$; otherwise $=0$ ). In doing so, a number of other variables were controlled which included woman's age (in years), her household headship status (head $=1$; otherwise $=0$ ), religion $($ Christian $=1$; otherwise $=0$ ), residential location (rural $=1$; otherwise $=0$ ), number of young children $(<=10$ years $)$, number of members to help with housework and non-housework (>10 years) and hours worked, a husband's years of schooling (in years), and household asset value (Ln). The choice of most of these variables is informed by the literature. All the variables are organized into three theoretical themes (i.e., time availability, relative resources, and gender ideology) and other demographic and socioeconomic variables controlled. The time availability variable is measured in terms of a woman's work status in activities outside of the home. The relative resources or bargaining is measured in terms of a woman's years of schooling and loan receipt. As regards gender ideology, previous research measured this variable variously. A number of studies (e. g. Davis et al., 2007; Fahlen, 2016; Fuwa, 2004) measured this concept with indexes based on responses to multiple statements. Fuwa (2004) 
used five statements describing gender ideology/display, Davis et al. (2007) added one more statement to Fuwa's variables, and Fahlen (2016) used two other statements. Whereas, others (e.g. Arrighi and Maume, 2000; Parkman, 2004) measured the concept with single items. All these authors asked respondents to decide the extent to which they agree or disagree with each of the statements; using a five point Likert scale (Fahlen used eight point scale). In the present paper, Likert scale items were not used. Instead, women were asked to list, using response category codes, all housework activities they performed and the time spent for each activity the last seven days before the survey date. For those women who reported higher housework participation and hours worked compared to that of their husbands (interviewer was responsible to check with that), women were further asked to decide if each of the three statements (Table 1) describes their reasons for doing much of the housework (yes/no responses). For developed countries, this approach may lead to significant reduction in sample size for this variable due to likely considerable proportion of women whose housework time is not larger than their husbands'. In the developing country context where women do more housework almost universally, this is unlikely. For example, $435(86.7 \%)$ women reported to have performed housework more than what was performed by men. This is quite a good number, and the author does not believe sample size to be a serious concern here.

Table 1: Women's response to gender ideology/display variables

\begin{tabular}{lcc}
\hline \multicolumn{1}{c}{ Gender ideology/display variable } & $\begin{array}{c}\text { Yes } \\
\mathrm{No}(\%)\end{array}$ & $\begin{array}{c}\text { No } \\
\mathrm{No}(\%)\end{array}$ \\
\hline $\begin{array}{l}\text { My job is to take care of housework as my } \\
\text { husband's job is to work for our living }\end{array}$ & $129(29.7)$ & $306(70.3)$ \\
$\begin{array}{l}\text { Everything in the house goes wrong when I } \\
\text { instead } \\
\text { of my husband work outside }\end{array}$ & $359(82.5)$ & $76(17.5)$ \\
$\begin{array}{l}\text { My husband is not experienced in these } \\
\text { activities, but I am }\end{array}$ & $274(63.0)$ & $161(37.0)$ \\
\hline
\end{tabular}

In terms of decision rule, a woman was considered traditional in her gender ideology/display if she responded yes to at least two of the variables (twothird). Based on this decision rule, 297 (68.3\%) of the women were found to have traditional gender ideology/display.

In terms of analytical technique, multivariate linear regression technique was employed to analyze quantitative data. While there are debates whether to use 
Chalachew Getahun

linear or other models for time use study, e.g. Tobit, according to Foster and Kalenkoski (2013) qualitative results (coefficient sign) obtained from both of them is similar, but tend to be statistically insignificant for Tobit model if there are more zeros in the data. Whereas others (e.g. Frazis and Stewart, 2012; Stewart, 2009) argue that linear models are more robust to measurement errors and should be preferred in the analysis of time allocation decisions. Several other empirical studies (e.g. Fahlen, 2016) used linear multivariate regression techniques. Following these past studies (Fahlen, 2016; Frazis and Stewart, 2012; Stewart, 2009), the present paper used multiple hierarchical linear regression to analyze determinants of women's time spent for housework. This makes sense especially in contexts (such as in Ethiopia) where housework is typically women's task and zero hours of work are limited, if not absent.

Given a continuous response outcome variable and a set of $k$ numerical predictor variables, $X_{1}, X_{2} \ldots X_{k}$, the multiple linear regression model is given by: $Y_{i}=\beta_{0}+\beta_{1} X_{1 i}+\beta_{2} X_{2 i}+\ldots+\beta_{k} X_{k i}+\varepsilon_{i}$

Where, $Y_{i}$ is time use in minutes per day of a member of the $i^{\text {th }}$ household; $\beta_{0}$ is the Y-intercept, the model-predicted value of the dependent variable when the value of every predictor is equal to $0 ; \beta_{1}, \beta_{2}, \beta_{k}$ are parameter coefficients of vectors of each $X_{1}, X_{2 i}, X_{k i}$; and $\varepsilon_{i}$ is the error term in the model for the $\mathrm{i}^{\text {th }}$ case.

The least squares estimator, $b$ of $\beta$ is given by:

$b_{i k}=\frac{N \sum X_{i k} Y_{i}-\left(\sum X_{i k}\right)\left(\sum Y_{i}\right)}{N \sum X_{i k}{ }^{2}-\left(\sum X_{i k}\right)^{2}}$

Where, $b_{i k}$ is the least squares estimator for the $i^{\text {th }}$ household of the $k^{\text {th }}$ variable; $N$ is the number of observations; $X_{i k}$ is the value of the given predictor variable $k$ for the $i^{\text {th }}$ household; and $Y_{i}$ is the value of the given predicted variable, $Y$ for the $i^{\text {th }}$ household.

\section{Results}

Characteristics of the Study: Women and their Time Spent in Housework

The tables below offer some descriptive statistics on the demographic and socioeconomic characteristics of sample women and their time spent on 
housework. Table 2 provides mean values for sample women for selected (continuous) variables. The table shows that, on average, women were about 45 years old; had close to 2 young children; had nearly 1 member in the household each helping with housework and non-housework (including the husband, more adult children, and/or other members); had schooling nearly 1.9 years lower than husband's schooling; had an asset equivalent to nearly 12767 ETB - Ethiopian Birr, and nearly 3 hours of housework and 1.7 hours of non-housework contribution of other members to the household. Finally, the table shows that women spent slightly more than 5.5 hours a day on domestic chores, on average. However, as Table 3 depicts, women's time spent varies by measures of time availability, relative resources and gender and by other relevant demographic and socioeconomic characteristics.

Table 2: Some demographic and economic characteristics of sample households (means)

\begin{tabular}{|c|c|c|}
\hline Variable & Mean(SD) & $\begin{array}{c}\text { Standard } \\
\text { errors of the } \\
\text { mean }\end{array}$ \\
\hline Respondent age & $\begin{array}{c}44.8750 \\
(10.9629)\end{array}$ & 0.69614 \\
\hline $\begin{array}{l}\text { Number of young children } \\
\text { (<10 years) }\end{array}$ & $\begin{array}{l}1.7258 \\
(1.4304)\end{array}$ & 0.09083 \\
\hline $\begin{array}{l}\text { Number of other members } \\
\text { involved in housework }\end{array}$ & $\begin{array}{c}1.2419 \\
(1.3639)\end{array}$ & 0.08661 \\
\hline $\begin{array}{l}\text { Number of other members } \\
\text { involved in non-housework }\end{array}$ & $\begin{array}{c}.8347 \\
(1.2143)\end{array}$ & 0.07711 \\
\hline $\begin{array}{l}\text { Respondent's years of } \\
\text { schooling }\end{array}$ & $\begin{array}{c}3.5363 \\
(4.4666)\end{array}$ & 0.28363 \\
\hline Husband's years of schooling & $\begin{array}{c}5.4375 \\
(5.1081)\end{array}$ & 0.32436 \\
\hline Value of household asset & $\begin{array}{c}12766.7 \\
(16420.5206)\end{array}$ & 1042.7 \\
\hline $\begin{array}{l}\text { Hours of housework by other } \\
\text { members }\end{array}$ & $\begin{array}{c}2.9906 \\
(2.9895)\end{array}$ & 0.18983 \\
\hline $\begin{array}{l}\text { Hours of non-housework by } \\
\text { other members }\end{array}$ & $\begin{array}{l}1.6895 \\
(1.8032)\end{array}$ & 0.1145 \\
\hline $\begin{array}{l}\text { Respondent hours of } \\
\text { housework }\end{array}$ & $\begin{array}{c}5.5357 \\
(4.0685) \\
\end{array}$ & 0.25940 \\
\hline
\end{tabular}


Table 3 presents women's housework by time availability, relative resources and gender and by other demographic and socioeconomic characteristics. In terms of time availability proxied by employment, the table depicts that $54 \%$ of the women are not employed, and that unemployed women spent nearly four times as many hours on housework per day as employed women. Regarding bargaining power, the table shows that nearly $53 \%$ of the sample women and $74.1 \%$ of their husbands attended some level of education. Nearly two-third of both women and men had attended primary school (1-8) followed by those who attended high school (one-fourth for women, and one-fifth for men), the proportion of those who attended post-secondary school being low. As the table shows, a woman's hours of housework generally decreased as couples became more educated (for the husband, however, the pattern tended to reverse with more years of schooling). As shall be discussed later on, however, there are other studies (discussed in section 3.2) which found highly educated women to spend more instead of less time for housework. In terms of loan receipt, the second proxy indicator for bargaining power, the table depicts that $43 \%$ of the women had received loan, and those women who had received loan had spent fewer hours in housework compared to those who did not receive loan. As regards gender, 435 (86.7\%) women reported to have performed more housework compared to what was performed by men. Of these, more than two-third of women reported to have traditional gender ideology or display. It shows that women with more traditional gender perception/practice spent more housework hours.

With regard to age and household headship, the table shows that $50 \%$ of the sample women are concentrated within the first two age groups which range from 25 to 44 years. In general, except for the third and the last age groups which deviate from the pattern, respondents appear to have spent more time with an increase in age, the least and the largest hour spent on housework being for women of ages 65 or more years and for women of ages 45-54 respectively. The largest time spent by women in the 45-54 age group instead of in the 35-44 age group is not in line with other studies (see e. g. Krantz-Kent 2009). Contrary to the results in this paper, the same study found women aged 65 to 74 spent more time in unpaid housework than did women aged 55 to 64 . For people aged 50 and older in general, the study found time spent on housework first to increase with age and then to decline. However, this seemingly contrasting result may be due to the long time expectancy for American women whose old age occurs much later than that of Ethiopian women. In general the results for persons aged 50 and older coincide with what one would expect to observe when individuals depart the labor force. Household head wise, the table shows that close to one-fifth of the sample women 
are heads of their households, and that women heads compared to non-heads spent slightly fewer hours in housework.

Regarding the number of young children, the table depicts that almost close to one-fourth of women do not have young children, a likely reason to explain the small average number of young children reported in Table 2. Table 3 shows that more than half of the sample women $(56.4 \%)$ have 2 or more children. In terms of time spent for housework, the table shows that women's time spent increases with an increase in the number of young children. However, this pattern did not hold for women with 3 or more young children where time spent tended to decline. One might think of childcare giver hiring by women with many young children as a possible reason for this, but this is not supported by data (not reported here) in which the majority of women having more than 2 children belonged to the lower wealth group (as measured by household assets), had fewer or no years of schooling and, did not receive loan. Therefore, as is argued above, the reason perhaps appears to be that these poor women, facing both time and resource shortage may have to cut housework hours in favor of working for earnings or have to combine them. In general, except for women with three or more children, the results are in line with the available evidence. For example, McGinnity and Russell's (2008) found that women with a young child under 5 years have almost 4 hours more total committed time per weekday than women without children. Similarly, Krantz-Kent (2009) found the time mothers spent doing unpaid household work to have increased by an average of almost 6 hours per week with the presence of one additional child.

As regards members helping with housework and non-housework, Table 3 shows that $81 \%$ of the sample households had members helping with housework, which includes husbands, adult children and/or other members. Of these, $43.7 \%$, $32.3 \%$ and $24 \%$ had 1,2 and 3 members respectively. On the other hand, $89.4 \%$ of the sample households had members helping with non-housework, 50.3\%, 29.5\% and $20.1 \%$ of which have 1,2 and 3 members respectively. In terms of hours of housework, the table shows that, in general, a woman's housework time decreased with an increase in the number of children to help with housework and increased with an increase in the number of members helping with non-housework. In a descriptive study of Tsimane in Bolivia, Ringhofer (2015) found substantial reduction of a woman's housework time by the presence of elderly women.

In terms of household assets, the table depicts that $61 \%$ of the households lie within the first two asset quartiles, and $22 \%$ within the highest asset quartile. For hours of housework, in general, time spent increased with an increase in the asset quartiles, except for the second quartile which has fewer hours of housework 
Chalachew Getahun

than the first quartile. When considering religion as a factor, interesting results appear. The table shows that nearly $85 \%$ of the sample women are followers of the Christian religion. It shows that Christian women provide slightly fewer hours of housework compared to non-Christian women. When it comes to residential location, the table shows women in the rural sub-sample compared to those in the urban sub-sample to have spent more time in housework.

Table 3: Women's housework by time availability, relative resources and gender and by other demographic and socioeconomic characteristics

\begin{tabular}{|c|c|c|c|}
\hline \multicolumn{2}{|c|}{ Variable } & \multirow[t]{2}{*}{ No. (\%) } & \multirow{2}{*}{$\begin{array}{c}\text { Time spent by } \\
\text { women } \\
\text { Hours } \\
\text { Mean(SD) }\end{array}$} \\
\hline & & & \\
\hline \multirow[t]{2}{*}{$\begin{array}{l}\text { Respondent is } \\
\text { employed* }\end{array}$} & Employed & $224(44.6)$ & $\begin{array}{c}2.4725 \\
(3.31999)\end{array}$ \\
\hline & $\begin{array}{l}\text { Not } \\
\text { employed }\end{array}$ & $278(54.4)$ & $\begin{array}{c}8.0543 \\
(2.65573)\end{array}$ \\
\hline \multirow[t]{5}{*}{$\begin{array}{l}\text { Respondent's years of } \\
\text { schooling }\end{array}$} & 0 & $237(47.2)$ & $\begin{array}{c}6.1855 \\
(4.18987)\end{array}$ \\
\hline & $1-4$ & $103(20.5)$ & $\begin{array}{c}6.5550 \\
(4.13138)\end{array}$ \\
\hline & $5-8$ & $72(14.3)$ & $\begin{array}{c}6.4330 \\
(4.35755)\end{array}$ \\
\hline & $9-12$ & $69(13.7)$ & $\begin{array}{c}5.5513 \\
(4.20590)\end{array}$ \\
\hline & $>12$ & $21(4.2)$ & $\begin{array}{c}4.9197 \\
(3.86559)\end{array}$ \\
\hline \multirow[t]{2}{*}{$\begin{array}{l}\text { Respondent received } \\
\text { loan }\end{array}$} & Received & $215(43.0)$ & $\begin{array}{c}4.7477 \\
(4.27513)\end{array}$ \\
\hline & Not received & 285(57.0) & $\begin{array}{c}6.1137 \\
(3.90620)\end{array}$ \\
\hline \multirow[t]{2}{*}{$\begin{array}{l}\text { Traditional gender } \\
\text { perception/practice }\end{array}$} & Traditional & 297(68.3) & $\begin{array}{c}6.8 \\
(4.2531)\end{array}$ \\
\hline & $\begin{array}{l}\text { Not } \\
\text { traditional }\end{array}$ & 138(31.7) & $\begin{array}{c}5.3 \\
(4.0153)\end{array}$ \\
\hline $\begin{array}{l}\text { Respondent is } \\
\text { household }\end{array}$ & Head & $92(18.7)$ & $\begin{array}{c}5.3671 \\
(4.10915)\end{array}$ \\
\hline
\end{tabular}


EJOSSAH Vol. 14, No. 2

\begin{tabular}{|c|c|c|c|}
\hline head & Not head & $405(81.3)$ & $\begin{array}{c}5.5734 \\
(4.06873)\end{array}$ \\
\hline \multirow[t]{5}{*}{ Respondent age } & $25-34$ & $88(17.5)$ & $\begin{array}{c}5.2358 \\
(4.39877)\end{array}$ \\
\hline & $35-44$ & $163(32.5)$ & $\begin{array}{c}5.4492 \\
(4.13848)\end{array}$ \\
\hline & $45-54$ & $155(30.9)$ & $\begin{array}{c}5.5103 \\
(3.74793)\end{array}$ \\
\hline & $55-64$ & $63(12.5)$ & $\begin{array}{c}6.5418 \\
(4.31253)\end{array}$ \\
\hline & $>=65$ & $33(6.6)$ & $\begin{array}{c}4.9800 \\
(4.01916)\end{array}$ \\
\hline \multirow{4}{*}{$\begin{array}{l}\text { Number of young } \\
\text { children } \\
(<10 \text { years })\end{array}$} & 0 & $117(23.3)$ & $\begin{array}{c}4.6309 \\
(4.06873)\end{array}$ \\
\hline & 1 & $102(20.3)$ & $\begin{array}{c}5.8245 \\
(4.19693)\end{array}$ \\
\hline & 2 & $159(31.7)$ & $\begin{array}{c}6.2518 \\
(3.65453)\end{array}$ \\
\hline & $>=3$ & $124(24.7)$ & $\begin{array}{c}5.4512 \\
(4.15310)\end{array}$ \\
\hline \multirow{4}{*}{$\begin{array}{l}\text { Number of other } \\
\text { members involved in } \\
\text { housework }\end{array}$} & 0 & $95(19.0)$ & $\begin{array}{c}6.1791 \\
(4.10027)\end{array}$ \\
\hline & 1 & $177(35.4)$ & $\begin{array}{c}4.7546 \\
(3.77852)\end{array}$ \\
\hline & 2 & $131(26.2)$ & $\begin{array}{c}4.2978 \\
(4.59136)\end{array}$ \\
\hline & $>=3$ & 97(19.4) & $\begin{array}{c}5.4193 \\
(4.00429)\end{array}$ \\
\hline \multirow[t]{5}{*}{$\begin{array}{l}\text { Husband's years of } \\
\text { schooling }\end{array}$} & 0 & $129(25.9)$ & $\begin{array}{c}5.8813 \\
(4.09759)\end{array}$ \\
\hline & $1-4$ & $127(25.5)$ & $\begin{array}{c}5.8106 \\
(3.71743)\end{array}$ \\
\hline & $5-8$ & $109(21.8)$ & $\begin{array}{c}4.6367 \\
(4.25729)\end{array}$ \\
\hline & $9-12$ & $81(16.2)$ & $\begin{array}{c}5.7871 \\
(4.10158)\end{array}$ \\
\hline & $>12$ & $53(10.6)$ & $\begin{array}{c}6.0460 \\
(4.36647)\end{array}$ \\
\hline
\end{tabular}

December 2018

$(4.06873)$

(n)


Chalachew Getahun

\begin{tabular}{|c|c|c|c|}
\hline \multirow{4}{*}{$\begin{array}{l}\text { Number of other } \\
\text { members involved in } \\
\text { non-housework }\end{array}$} & 0 & $53(10.6)$ & $\begin{array}{c}4.4829 \\
(3.83595)\end{array}$ \\
\hline & 1 & $225(45.0)$ & $\begin{array}{c}4.4165 \\
(3.84234)\end{array}$ \\
\hline & 2 & $132(26.4)$ & $\begin{array}{c}5.0173 \\
(3.85751)\end{array}$ \\
\hline & $>=3$ & $90(18.0)$ & $\begin{array}{c}5.1791 \\
(4.10553)\end{array}$ \\
\hline \multirow[t]{4}{*}{ Value of assets owned } & $\begin{array}{l}1^{\text {st }} \text { quartile } \\
(3630)\end{array}$ & 194(38.7) & $\begin{array}{c}5.5631 \\
(3.80811)\end{array}$ \\
\hline & $\begin{array}{l}2^{\text {nd }} \text { quartile } \\
(8012)\end{array}$ & $113(22.5)$ & $\begin{array}{c}4.6991 \\
(4.15832)\end{array}$ \\
\hline & $\begin{array}{l}3^{\text {rd }} \text { quartile } \\
(16795)\end{array}$ & $85(16.9)$ & $\begin{array}{c}5.5844 \\
(4.44971)\end{array}$ \\
\hline & Top quartile & $110(21.9)$ & $\begin{array}{c}5.8523 \\
(3.95154)\end{array}$ \\
\hline \multirow[t]{2}{*}{ Religion } & Christian & $422(84.7)$ & $\begin{array}{l}4.93017 \\
(4.1276)\end{array}$ \\
\hline & Other & $76(15.3)$ & $\begin{array}{l}5.43421 \\
(5.5521)\end{array}$ \\
\hline \multirow[t]{2}{*}{ Rural residence } & Rural & $247(49.2)$ & $\begin{array}{c}5.7897 \\
(4.09067)\end{array}$ \\
\hline & Urban & $255(50.8)$ & $\begin{array}{c}5.2857 \\
(4.04752)\end{array}$ \\
\hline
\end{tabular}

* broadly defined to include women working for wage and/or are self-employed whether for wage or own consumption.

\section{Determinants of Time Use for Household Activities}

Having described women's time spent on housework by individual and household demographic and socioeconomic characteristics in the forgoing sub-section, I now turn on to using a multivariate hierarchical linear model. The dependent variable for the model is a woman's time (in minutes) spent on housework per day (see section 3.2 for the list and measurement of independent variables). The table presents results for time availability, relative resources/bargaining, and gender ideology/display as determinants of a woman's housework time as discussed in the theoretical literature, and controlling for other demographic and socioeconomic variables. Although the purpose of controlling for other variables is to show the effect of the key study variables of interest above and beyond the contributions of 20 
control variables, I have also discussed the controls in presenting and discussing the results, and this is especially important given the absence of past research on Ethiopia.

Seven models were estimated. In the first three models, only the three key explanatory variables of interest were included. First, time availability predictor alone was included, then resources or bargaining variables and gender variables were added in the second and third models respectively. The fourth model included control variables without the key variables of interest. The last three models added the key variables of interest to these controls in each of the next three models - first time availability in model 5 and then the resources or bargaining and the gender variables in models 6 and 7 respectively. The objective was to see patterns of the association between these key variable clusters and a woman's hours of work with and without controls.

As is shown in the table, a woman's employment status (a shift from being unemployed coded 0 to employed coded 1 ) as a measure of time availability has a strong, statistically significant negative association with her housework time, for all the six models despite its being slightly weaker after taking account of control variables and as the resource or bargaining and the gender variables were added. Regarding the variables representing relative resources or bargaining, a woman's schooling years and her loan receipt status (a shift from not receiving loan coded 0 to receiving coded 1) have statistically significant negative association with her housework time. Note that, before the control variables were included, a woman's years of schooling compared to her loan receipt status variable had a statistically stronger significant association with her housework hours, both before and after including the gender variable. However, this situation reversed after control variables were included, the statistical significance test value getting stronger for loan receipt and weaker for years of schooling. Finally, a woman with traditional gender ideology/display (a shift from egalitarian gender perception/practice coded 0 to a traditional one coded 1) has a statistically significant positive association with her housework time, but the association is statistically weak whether with or without control variables.

Before the key variable clusters were added, three control variables, namely, respondent's age, number of members involved in housework and their housework time had statistically significant (but weaker for respondent's age) negative association to a woman's housework time. After the key variable clusters were added, the members hours of housework variable retained its statistical significance level, but the respondent's age variable was no longer statistically significant for all the next three models, whereas the level of statistical significance 
for the number of members involved in housework variable became weaker after the time availability variable was added, and then became no longer statistically significant after the resources and gender variables were added in the next two models. By contrast, the remaining five variables, namely, number of young children, number of members involved in non-housework, members' hours of nonhousework, value of household assets, and rural location (a shift from urban coded 0 to rural coded 1 ) had a statistically significant positive association with a woman's hours of housework (but statistical significance is weaker for the number of members involved in non-housework and rural location variables).

Table 4: Parameter coefficients for determinants of women's time spent for housework $(\mathrm{N}=502)$

\begin{tabular}{|c|c|c|c|c|c|c|c|c|}
\hline \multicolumn{2}{|c|}{ Variables } & \multicolumn{7}{|c|}{ Models } \\
\hline & & 1 & 2 & 3 & 4 & 5 & 6 & 7 \\
\hline $\begin{array}{l}\text { Time } \\
\text { availabili } \\
\text { ty }\end{array}$ & $\begin{array}{l}\text { Respondent is } \\
\text { employed }\end{array}$ & $\begin{array}{c}- \\
5.732 * * * \\
(0.381)\end{array}$ & $\begin{array}{l}- \\
5.667 * * \\
* \\
(0.383)\end{array}$ & $\begin{array}{c}- \\
5.582 * * \\
* \\
(0.384)\end{array}$ & & $\begin{array}{c}- \\
5.162 * * \\
(0.453)\end{array}$ & $\begin{array}{c}- \\
5.064 * * \\
(0.424)\end{array}$ & $\begin{array}{c}- \\
4.716^{* *} \\
(0.382)\end{array}$ \\
\hline $\begin{array}{l}\text { Relative } \\
\text { resource } \\
\text { s/ }\end{array}$ & $\begin{array}{l}\text { Respondent's } \\
\text { years of } \\
\text { schooling }\end{array}$ & & $\begin{array}{c}- \\
0.121 * * \\
(0.048)\end{array}$ & $\begin{array}{c}- \\
0.138 * * \\
(0.053)\end{array}$ & & & $\begin{array}{c}-0.113 * \\
(0.253)\end{array}$ & $\begin{array}{l}-0.099 * \\
(0.053)\end{array}$ \\
\hline $\begin{array}{l}\text { bargainı } \\
\text { ng }\end{array}$ & $\begin{array}{l}\text { Respondent } \\
\text { received loan }\end{array}$ & & $\begin{array}{l}-0.329 * \\
(0.383)\end{array}$ & $\begin{array}{l}-0.293 * \\
(0.386)\end{array}$ & & & $\begin{array}{c}- \\
0.301 * * \\
(0.209)\end{array}$ & $\begin{array}{c}- \\
0.234 * * \\
(0.381)\end{array}$ \\
\hline $\begin{array}{l}\text { Gender } \\
\text { ideology } \\
\text { / display }\end{array}$ & $\begin{array}{l}\text { Traditional } \\
\text { gender } \\
\text { perception/prac } \\
\text { tice }\end{array}$ & & & $\begin{array}{l}0.532 * \\
(0.242)\end{array}$ & & & & $\begin{array}{l}0.351 * \\
(0.921)\end{array}$ \\
\hline $\begin{array}{l}\text { Control } \\
\text { variables }\end{array}$ & $\begin{array}{l}\text { Respondent is } \\
\text { household head }\end{array}$ & & & & $\begin{array}{l}-0.904 \\
(0.545)\end{array}$ & $\begin{array}{l}-0.831 \\
(0.501)\end{array}$ & $\begin{array}{l}-0.887 \\
(0.513)\end{array}$ & $\begin{array}{l}-0.754 \\
(0.487)\end{array}$ \\
\hline & $\begin{array}{l}\text { Respondent's } \\
\text { age }\end{array}$ & & & & $\begin{array}{c}-0.197 * \\
(0.098)\end{array}$ & $\begin{array}{l}-0.135 \\
(0.045)\end{array}$ & $\begin{array}{l}-0.225 \\
(0.122)\end{array}$ & $\begin{array}{l}-0.025 \\
(0.022)\end{array}$ \\
\hline & $\begin{array}{l}\text { Number of } \\
\text { children below } \\
10 \text { years }\end{array}$ & & & & $\begin{array}{l}0.526^{*} \\
* * \\
(0.251)\end{array}$ & $\begin{array}{c}0.488 * * \\
* \\
(0.192)\end{array}$ & $\begin{array}{c}0.462 * * \\
(0.179)\end{array}$ & $\begin{array}{c}0.362 * * \\
(0.152)\end{array}$ \\
\hline
\end{tabular}


EJOSSAH Vol. 14, No. 2

December 2018

\begin{tabular}{|c|c|c|c|c|}
\hline $\begin{array}{l}\text { Number of } \\
\text { members } \\
\text { involved in } \\
\text { housework }\end{array}$ & $\begin{array}{c}-\overline{-} \\
0.299 * \\
* \\
(0.171)\end{array}$ & $\begin{array}{l}-0.401 * \\
(0.165)\end{array}$ & $\begin{array}{c}-0.388 \\
(0.157)\end{array}$ & $\begin{array}{l}-0.208 \\
(0.165)\end{array}$ \\
\hline $\begin{array}{l}\text { Number of } \\
\text { members } \\
\text { involved in } \\
\text { non-housework }\end{array}$ & $\begin{array}{l}0.304 * \\
(0.213)\end{array}$ & $\begin{array}{c}0.321 \\
(0.222)\end{array}$ & $\begin{array}{c}0.291 \\
(0.20 .9)\end{array}$ & $\begin{array}{c}0.188 \\
(0.179)\end{array}$ \\
\hline $\begin{array}{l}\text { Members' } \\
\text { housework } \\
\text { hours }\end{array}$ & $\begin{array}{c}- \\
0.261 * \\
* \\
(0.111)\end{array}$ & $\begin{array}{c}- \\
0.276^{* * *} \\
(0.166)\end{array}$ & $\begin{array}{c}- \\
0.297 * * \\
(0.168)\end{array}$ & $\begin{array}{c}- \\
0.243^{*} * \\
(0.071)\end{array}$ \\
\hline $\begin{array}{l}\text { Members' non- } \\
\text { housework } \\
\text { hours }\end{array}$ & $\begin{array}{c}0.362 * \\
* \\
(0.206)\end{array}$ & $\begin{array}{c}0.311 * * \\
(0.203)\end{array}$ & $\begin{array}{c}0.346^{* * *} \\
(0.221)\end{array}$ & $\begin{array}{c}0.254 * * \\
(0.126)\end{array}$ \\
\hline $\begin{array}{l}\text { Husband's } \\
\text { years of } \\
\text { schooling }\end{array}$ & $\begin{array}{l}-0.147 \\
(0.155)\end{array}$ & $\begin{array}{l}-0.139 \\
(0.128)\end{array}$ & $\begin{array}{c}-0.134 \\
(0.106)\end{array}$ & $\begin{array}{l}-0.106 \\
(0.052)\end{array}$ \\
\hline $\begin{array}{l}\text { Value of } \\
\text { household } \\
\text { assets (Ln) }\end{array}$ & $\begin{array}{c}0.661 * \\
* \\
(0.217)\end{array}$ & $\begin{array}{c}0.665 * * \\
(0.219)\end{array}$ & $\begin{array}{c}0.634 * * \\
(0.217)\end{array}$ & $\begin{array}{c}0.508 * * \\
(0.201)\end{array}$ \\
\hline $\begin{array}{l}\text { Christian } \\
\text { religion }\end{array}$ & $\begin{array}{l}-1.841 \\
(0.904)\end{array}$ & $\begin{array}{c}-1.674 \\
(0.701)\end{array}$ & $\begin{array}{l}-1.695 \\
(0.868)\end{array}$ & $\begin{array}{c}-1.652 \\
(0.0854)\end{array}$ \\
\hline Rural location & $\begin{array}{l}0.509 * \\
(0.231)\end{array}$ & $\begin{array}{c}0.502 \\
(0.242)\end{array}$ & $\begin{array}{l}0.503^{*} \\
(0.354)\end{array}$ & $\begin{array}{c}0.491 \\
(0.536)\end{array}$ \\
\hline
\end{tabular}

\begin{tabular}{cccccccc}
\hline $\mathrm{R}^{2}$ & 0.166 & 0.184 & 0.199 & 0.476 & 0.509 & 0.519 & 0.542 \\
& & & & & & & \\
& & & & & & & \\
$\Delta R^{2}$ & & 0.018 & 0.015 & 0.277 & 0.033 & 0.01 & 0.023
\end{tabular}




\begin{tabular}{lccccccc}
\multicolumn{1}{c}{ Chalachew Getahun } \\
\hline $\mathrm{F}$ & $214.634^{*}$ & $56.276^{*}$ & $45.062^{*}$ & 18.223 & $32.185^{*}$ & $26.087^{*}$ & $24.699^{*}$ \\
$* *$ & $* *$ & $* *$ & $* *$ & $* *$ & $* *$ & $* *$
\end{tabular}

$* * *=\mathrm{p}<0.01 ; * *=\mathrm{p}<0.05 ; *=\mathrm{p}<0.1$. Standard errors are reported in parenthesis.

\section{Discussion}

Time availability

As was discussed in the literature, employed women are expected to be less likely to spend much time in housework. Available empirical work (e g. Artis and Pavalko, 2003; Bernando et al., 2014; Campaña, et al., 2017; Cunningham, 2007; Davis et al., 2007; Fahlen, 2016; Fuwa, 2004; McGinnity and Russell, 2008; Pinto and Coltrane, 2008; Tsuya, et al., 2000) confirmed this expectation. In the present paper, the statistically significant association between a woman's being employed and her hours of housework is in line with this evidence base. However, there needs to be caution in its interpretation since part of the reason may lie in the way it is defined. Unlike for the developed countries where it is defined in terms of wage employment, it is here broadly defined to include working for wage and/or self-employed. This definition appears to be more realistic given the country's context where paid or market work opportunities are very limited, and even where they exist they are dominated by informal employment (Chalachew, 2018). So, in this case, the large coefficient is surprising given the lack of very clear distinction between housework and non-housework, especially for farming and the informal sector. On the other hand, it may be explained by the high level of poverty whether defined in terms of food, income or employment which may have forced women to work more thereby reducing their housework time. In explaining the lack of negative effect of the number of children on maternal labor market participation in Ethiopia, Solomon and Kimmel (2009) for example argued that Ethiopian women may not afford to stop working in the face of high unemployment rate even when they have young children in need of care.

\section{Resources or Bargaining}

Theoretically it is assumed that resources available to the individual in a household enable individuals to bargain away from housework. Past research commonly used education and income indicators to measure this variable. In the present paper, I have used years of schooling and loan receipt. Women's participation and time spent in housework is expected to decrease with an increase in their education, especially higher education since it is associated with higher opportunity cost of 
doing housework. Hours of housework is also expected to decrease with an increase in husband's years of schooling. Much of the available empirical evidence is consistent with this prediction (see e. g. Bardasi and Wodon 2010; Campaña, et al. 2017; Fahlen, 2016; Fuwa, 2004; Gammage, 2010; Gimenez-Nadal and Sevilla, 2012; Guryan, Hurst and Kearney, 2008; McGinnity and Russell, 2008; Tsuya et al., 2000). On the other hand, analyzing their own data, Campaña, Gimenez-Nadal and Molina (2017) found negative but mostly statistically insignificant effect of education for most of the countries studied (Mexico, Ecuador, Panama, and Peru). Despite the weak statistical significance after taking account of control variables, the negative association between a woman's years of schooling and her hours of housework for the present paper is in line with this evidence base. There are, however, some other studies (e.g. Bernardo et al., 2014; Davis et al., 2007; Golden, 2008; Newman, 2001; Singh et al., 2013) that showed highly educated women (bachelor degree or higher) to be less likely to work outside of home relative to respondents with low educational attainment. Some authors (e.g. Golden, 2008; Singh et al., 2013) attributed this to women's increased ability to bargain (with employer) to work from home. However, the Ethiopian context is very different in that it is unrealistic to think that, in the midst of high unemployment rate and widespread poverty, education has increased the capability of Ethiopian women to negotiate to work from home. Nor are there any facilities to allow working from home, even if we assume that negotiation was possible.

As is noted, defining relative resources in term of income or earnings, most past research (e. g. Davis et al., 2007; Parkman, 2004) found statistically significant negative effects on women's housework. Fuwa (2004) also found negative effect, but not statistically significant. However, for the present paper, loan receipt is used instead given that income is not available (or is very irregular) to most households, especially to farming women. Increasing poor households' access to credit services and empowering women through lending has been one of the key poverty reduction strategies of developing countries including Ethiopia. Garikipati (2012) argues that lending to women is expected to help them to shift their time from housework to market work, and from wage-work to selfemployment, which is considerably better remunerated, enhances the value of their incomes, and improves their self-esteem and empower them. However, most past research guided by household economic theory has focused on examining the effect of credit on women's labor market participation. Studies examining its effect on time use are not available, especially on housework. Garikipati's (2012) study is an exception to this lack of research, which, however, did not find the expected effect, using her own data: found positive but statistically insignificant effect of 
credit on housework time. In the present paper, the negative and statistically significant association between a woman's receiving loan and her hours of housework contradicts Garikipati's (2012) finding, but it is in line with the theoretical expectation. Apart from the opportunity costs ensued, the loan enables women to start own business by avoiding the lack of working capital and by increasing their bargaining power away from housework.

\section{Gender Ideology/Display}

As discussed in section 2.3, the gender ideology/display perspective posits that individuals are socialized to remain disproportionately responsible for the housework solely because of their gender, regardless of their economic resources or time availability. Research has consistently shown that there are persistent views regarding how women and men are expected to behave (Arrighi and Maume, 2000; Cunningham, 2001; Davis et al., 2007; Geist and Ruppanner, 2018; Fahlen, 2016; Fuwa, 2004). In line with the gender perspective, Fahlen (2016) and Fuwa (2004) found a strong statistically significant negative effect of egalitarian gender attitudes on women's hours of work. Similarly, Davis et al., (2007), found a positive effect (coefficient at least twice as large as its standard error) of more traditional gender ideology on housework. On the other hand, estimating separate models for different housework indicators, Parkman (2004) found mixed results of traditional gender ideology on women's housework: negative for meal preparation, washing dishes, cleaning house, shopping, car maintenance, and driving and positive for washing/ironing and paying bills. The negative association between a woman's traditional gender perception/practice and her housework time in the present paper appears to be in line with the gender perspective, but the statistical significance is weak.

\section{Control Variables}

Research shows that women household heads compared to non-heads face time shortage. For example, a review of work by Blackden and Wodon (2006) for subSaharan Africa found women household heads to face greater time constraints than do male heads or other women, especially if such women have no other adult women to help with housework. Although the negative coefficient on headship for the present paper does not appear to be in line with this evidence base, the result is not statistically significant. While the lack of statistical significance may be due to problems in data quality, a possible reason for the negative coefficient could be that since such women are likely to be lone earners (non-head husbands/male partners are likely to be non-earners or earn less than women), the whole 
responsibility of feeding and maintaining the household rests solely, or at least mostly upon them, leading to fewer hours allocated for housework and more hours for earnings and/or food production. Given the informal nature of farming and of urban economic activities in the developing countries including Ethiopia (Chalachew, 2018), it is also likely that they can combine housework and nonhousework. In one way or the other, as Buvinic and Gupta (1997) remarked, this can lead them to lower paying jobs more compatible with housework, and this is likely to worsen their wellbeing. One could, however, also argue that if non-head husbands are non-earners or earn less than women, then, consistent to the bargaining or relative resources hypothesis, men may take on much of the housework, thus compensating for wife's reduced time for housework.

Age is an important factor influencing a woman's housework time (see e.g. Bardasi \& Wodon, 2010; Campaña et al., 2017; Erdil, Eruygur and Kasnakoglu, 2006; Gammage, 2010; Krantz-Kent, 2009; Tsuya, et al., 2000). As age progresses, especially after individuals depart the labor force because of old age, women will spend more time on household work (Krantz-Kent 2009). In line with this, Gammage (2010) found statistically significant positive effect of age for Guatemala. Similar effects were found by Davis et al. (2007) and Fuwa (2004) for 28 and 22 developed countries respectively. Whereas, Campaña, et al. (2017) found negative yet statistically insignificant effect of age for Columbia, Ecuador, Panama, and Peru but not for Mexico. The negative but statistically insignificant coefficient for the present paper echoes the latter evidence.

In terms of young children, research has shown its significant positive effect on women's housework time (Baxter, Hewitt, and Haynes, 2008; Bianchi et al., 2000; Davis et al., 2007; Fahlen 2016; Fuwa, 2004). The statistically significant positive association between number of young children a woman has and her hours of housework in the present article is in line with this and other available evidence. For example, except a few studies (e.g. Arora 2015; Bardasi and Wodon 2010) which found a maternal housework time reducing effect of young children, most other studies (e.g. Bianchi et al., 2000; Bernardo et al., 2014; Campaña et al., 2017; Craig, 2006; Gammage, 2010; Fahlen, 2016; Krantz-Kent, 2009; Tsuya, et al., 2000) generally found young children to increase housework hours for women. For example, Tsuya et al. (2000) found wives' household task hours to have increased significantly with presence especially of preschool but also school age children for Japan, USA and Korea. Bernardo et al. (2014), found a high maternal propensity for investing time in in-home childcare when there are young children of ages 0-5 years in the household, and decreases with an increase in the age of children. 
As regards members helping with housework and non-housework, it is expected that presence of members (including husbands) to help with maternal housework reduces a woman's time for domestic chores and increases her nonhousework time, whereas presence of members to help with non-housework is expected to increase her time in housework (see e.g. Campaña et al., 2017 and the references therein; World Bank, 2001). Empirically, in the context of time poverty, Arora (2015) and Campaña et al. (2017) found a statistically significant negative effect of presence of housework help on women's housework time allocation; and Davis et al. (2007) found positive effect of presence of employed members (in this case husbands) on women's housework time. However, there are other studies whose findings contradict with the above-noted studies. For example, Tsuya et al. (2000) found other members' housework contribution to be weak to decrease wives' housework time for Japan, USA and Korea, suggesting that these women adjusted their time either by adding paid employment to domestic responsibilities or by reducing the time spent in housework. Similarly, Gammage (2010) found presence of unemployed adult members to have positive (instead of negative) though statistically insignificant effect, and presence of wage earning adult members to have negative and statistically significant effect on a woman's' housework time. Despite the negative association between the number of members involved in housework and a woman's hours of housework for this paper as can be expected, coefficients is not statistically significant.

One possible explanation for the result's lack of statistical significance may lie in the possible confounding effects of age and sex composition of the members (see e.g. Blackden and Wodon, 2006). Studies show presence of more adult (vs. young) women (vs. men) to reduce a woman's hours of housework. For example, in the context of labor force hours worked, Hallman et al. (2005) for Guatemala City found that a mother is more likely to work outside and work more hours if there are substitute adult female caregivers in the household. No such variables were controlled in the model for the present paper, however. Given the absence of these variables, members' hours of housework and non-housework instead of their sheer number were also included in the model. As can be expected, an increase in members' hours of housework and non-housework is associated, respectively, with a decrease and an increase in a woman's hours of housework, both of which were statistically significant.

Although, in most traditional societies, economic factors (including assets) are only secondary to non-economic factors in explaining differences in time allocation, such factors can explain some of the differences (Ilahi, 2000; World Bank, 2001). According to Arora (2015) and World Bank (2001), asset ownership 
reduces the gender division of labor within the household. A study for Peru reported that the highest hours of housework by women within the lowest asset group (Ilahi, 2000). By contrast, Arora (2015) found that value of assets increased women's time poverty, implying absence of meaningful bargaining power improvement, although the effect was not statistically significant. The positive and statistically significant association between the household's assets ownership and a woman's hours of housework for the present paper echoes Arora's (2015) finding, although asset ownership in the present paper is defined at household level, instead of individual level.

In terms of religion, Bardasi and Wodon (2010) for Guinea and Mexico, and Campaña et al. (2017) for Ecuador, Panama, Peru and Columbia found positive effect of being Christian on time of poverty. For the present study, being Christian and women's hours of housework are negatively associated. However, neither of the results for the above-mentioned studies nor for the present one are statistically significant.

Finally, given the less scheduled, more flexible nature of rural jobs in relation to urban jobs, it is reasonable to assume that being in rural area compared to urban area is likely to increase housework time. Empirically, Campaña, et al.'s (2017) study found statistically significant positive effect of the rural dummy for Mexico, Peru, Ecuador, and Columbia. Similarly, Gammage (2010) indicated that being in a rural area reduces the probability of being time poor for Guatemala. These two past findings are not contradictory since a rural woman compared to an urban woman may spend more hours of housework, and yet can be time-non-poor since there is relatively less market work in rural areas. For the present paper, the association is positive, but its statistical significance is not quite strong.

\section{Conclusion}

This paper used a household survey of 502 married women in Bahir Dar City and rural villages of two nearby districts to analyze the determinants of Ethiopian women's hours of housework in light of available theories, namely, time availability, bargaining, gender ideology/display and other demographic and socioeconomic variables.

A woman's employment status, her years of schooling and loan receipt status, as a measures, respectively, of time availability and resources or bargaining power have statistically significant negative associations with a woman's housework time, even after controlling other demographic and socioeconomic variables. Similarly, traditional gender perception/practice as a measure of gender ideology/display has the expected positive association with a woman's housework 
Chalachew Getahun

time, despite the weaker statistical significance level. Of the control variables, housework performed by other members has statistically significantly negatively associated with a woman's housework time, whereas number of young children, non-housework performed by other members and household asset values are statistically significantly positively associated with her housework time, even after the three key variable clusters were added. The result for the first three control variables is also in line with the available literature.

National strategies aiming at poverty reduction may need to pay more attention to educate women, help them overcome working capital shortage, and improve employment opportunities since these may also empower women and thereby minimize traditional gender ideology/display and having too many young children. 


\section{References}

Aassve, A., Fuochi, G., \& Mencarini, L. (2014). Desperate housework: relative resources, time availability, economic dependency, and gender ideology across Europe. Journal of Family Issues, 35(8), 1000-1022.

DOI: $10.1177 / 0192513 X 14522248$

Arora, D. (2015). Gender differences in time-poverty in rural Mozambique. Review of Social Economy, 73(2), 196-221.

DOI: 10.1080/00346764.2015.1035909

Arora, D., \& Rada C. (2013). Gender differences in time and resource allocation in rural households in Ethiopia. Retrieved from https://pdfs.semanticscholar.org/a0f5/983dd2209da8d5719ef6bb35df072a 420368.pdf?_ga=2.90511386.1692339829.1555915351787280131.15365 2849

Arrighi, B. A., \& Maume, D. J. (2000). Workplace subordination and men's avoidance of housework. Journal of Family Issues, 21 (4), 464-487.

Artis, J. E., \& Pavalko, E. K. (2003). Explaining the decline in women's household labor: Individual change and cohort differences. Journal of Marriage and Family, 65, 746-761.

Asnakech Habtam Tamene, \& Chalachew Getahun Desta. (2015). Demographic and socioeconomic determinants of time use for household activities: A study in Kolfe Keranyo Sub city, Addis Ababa, Ethiopia. Ethiopian ejournal for Research and Innovation foresight, 7(1), 40-54.

Badr, H., \& Acitelli, L. K. (2008). Attachment insecurity and perceptions of housework: Associations with marital well-being. Journal of Family Psychology, 22(2), 313-319.

Bardasi, E., \& Wodon, Q. (2010). Working long hours and having no choice: Time poverty in Guinea. Feminist Economics, 16(3), 45-78. DOI: 10.1080/13545701.2010.508574.

Bartley, S. J., Blanton, P. W., \& Gilliard, J. L. (2005). Husbands and wives in dual-earner marriages: Decision-making, gender role attitudes, division of household labor, and equity. Marriage \& Family Review, 37(4), 69-94. DOI: 10.1300/J002v37n04_05

Batalova, J. A., \& Cohen, P. N. (2002). Premarital cohabitation and housework: Couples in cross-national perspective. Journal of Marriage and Family, 64, 743-755.

Baxter, J. (2002). Patterns of change and stability in the gender division of household labour in Australia, 1986-1997. Journal of Sociology, 38(4), 399-424. 
Chalachew Getahun

Baxter, J. Hewitt, B., \& Haynes, M. (2008). Life course transitions and housework: Marriage, parenthood, and time on housework. Journal of Marriage and Family, 70, 259-272.

Beaujot, R. (2001). Earning and caring: Demographic change and policy implications. PSC Discussion Papers Series, 15(5), 1-18. Retrieved from http://ir.lib.uwo.ca/pscpapers/vol15/iss5/1

Bernardo, C. Paleti, R., Hoklas, M., \& Bhat, C. (2014). An Empirical Investigation into the Time-Use and Activity Patterns of Dual-Earner Couples With and Without Young Children. Retrieved from https://www.caee.utexas.edu/prof/bhat/ABSTRACTS/Time_Use_Paper.p df

Bianchi, S. M., Milkie, M. A., Sayer, L. C., \& Robinson, J. P. (2000). Is anyone doing the housework? Trends in the gender division of household labor. Social Forces, 79(1), 191-228.

Bianchi, S. M., Sayer, L. C., Milkie, M. A., \& Robinson, J. P. (2012). Housework: Who did, does or will do it, and how much does It matter? Soc Forces, 91(1), 55-63. doi:10.1093/sf/sos120.

Bittman, M., England, P., Folbre, N., Sayer, L., \& Matheson, G. (2003). When does gender trump money? Bargaining and time in household work. American Journal of Sociology, 109(1), 186-214.

Blackden, C., M., \& Wodon, Q. (2006). Gender, Time use, and Poverty in Sub Saharan Africa (World Bank Working Paper, No. 73). DOI: 10.1596/9780-8213-6561-8.

Burchardt, T. (2008). Time and income poverty: Center for analysis of Social Exclusion (Report No. 57). London: School of Economics and Political Science. Retrieved from http://sticerd.lse.ac.uk/case/publications/reports.asp

Buvinic, M., \& Gupta, R. G. (1997). Female-headed households and female maintained families: Are they worth targeting to reduce poverty in developing countries. Economic Development and Cultural Change, 45(2), 259-280.

Campaña, J. C., Gimenez-Nadal, J. I., \& Molina, J. A. (2017). Differences between self-employed and employed mothers in balancing family and work responsibilities: Evidence from Latin American countries (MPRA, Paper No. 77964).

Retrieved from https://mpra.ub.unimuenchen.de/77964/

Canelas, C., \& Salazar, S. (2014). Gender and ethnic inequalities in LAC Countries. IZA Journal of Labor \& Development, 3(18), 1-15. 
Central Statistical Agency of Ethiopia and ORC Macro. (2005). The Ethiopian Demographic Health Survey. Addis Ababa.

Central Statistical Agency of Ethiopia. (2014). Ethiopian time use survey 2013. Addis Ababa.

Chalachew Getahun Desta. (2013). Fertility and maternal hours of work in Ethiopia: A case study in the Amhara region. African Population Studies, 27(2), 89-104. Retrieved from https://doi.org/10.11564/0-0-431

Chalachew Getahun Desta. (2017). Do young children prohibit mothers from working? A study in the Amhara Region, Ethiopia. International Journal of Population Studies 3 (2): 29-42.

Chalachew Getahun Desta. (2018). The Urban informal economy in Ethiopia: Theory and empirical evidence. Eastern Africa Social Science Research Review, 34(1), 37-63.

Ciabattari, T. (2004). Cohabitation and housework: The effects of marital intentions. Journal of Marriage and Family, 66, 118-125.

Coltrane, S. (2000). Research on household labor: Modeling and measuring the social embeddedness of routine family work. Journal of Marriage and the Family, 62(4), 1208-1233.

Craig, L. (2006). Children and the revolution: A time-diary analysis of the impact of motherhood on daily workload. Journal of Sociology, 42(2), 125-143. DOI: $10.1177 / 1440783306064942$

Cunningham, M. (2001). Parental influences on the gendered division of housework. American Sociological Review, 66, 184-203.

Cunningham, M. (2007). Influences of women's employment on the gendered division of household labor over the life course: Evidence from a 31-Year panel study. Journal of Family Issues, 28(3), 422-444.

Davis, S. N, \& Greenstein, T. N. (2004). Cross-national variations in the division of household labor. Journal of Marriage and Family, 66, 1260-1271.

Davis, S.N., Greenstein, T. N., \& Marks, J. P. G. (2007). Effects of union type on division of household labor: Do cohabiting men really perform more housework? Journal of Family Issues, 28(9), 1246-1272. DOI:10.1177/0192513X07300968

Deding, M., \& Lausten, M. (2006). Choosing between his time and her time? Paid and unpaid work of Danish couples. Electronic International Journal of Time Use Research, 3(1), 28-48. dx.doi.org/10.13085/eIJTUR.3.1

Dempsey, K. (2002). "Who gets the best deal from marriage: women or men? Journal of Sociology, 38(2), 91-110.

Erdil, E., Eruygur, O., \& Kasnakolu, Z. (2006). Time Use in rural areas: A case 
Chalachew Getahun

study in Turkey (Working Papers in Economics 06/02, Economic Research Center (ERC)). Ankara, Middle East Technical University.

Retrieved from https://www.erc.metu.edu.tr

Erickson, R. J. (2005). Why emotion work matters: Sex, gender, and the division of household labor. Journal of Marriage and Family, 67, 337-351.

Evertsson, M, \& Nermo, M. (2004). Dependence within families and the division of labor: Comparing Sweden and the United States. Journal of Marriage and Family, 66, 1272-1286.

Evertsson, M, \& Nermo, M. (2007). Changing resources and the division of housework: A longitudinal study of Swedish couples. European Sociological Review, 23(4), 455-470. DOI:10.1093/esr/jcm018

Fahlen, S. (2016). Equality at home - A question of career? Housework, norms, and policies in a European comparative perspective. Demographic Research, 35(48), 1411-1440. DOI: 10.4054/DemRes.2016.35.48

Fisher, K., \& Robinson, J. (2011). Daily life in 23 countries. Soc Indic Res, 101, 295-304. DOI 10.1007/s1 1205-010-9650-3

Floro, M. S., \& Miles, M. (2001). Time use and overlapping activities: Evidence from Australia. Sydney: The Social Policy Research Centre, University of New South Wales.

Folbre, N. (2006). Measuring care: Gender, empowerment, and the care economy. Journal of Human Development, 7(2), 183-200.

Foster, G., \& Kalenkoski, C. M. (2013). Tobit or OLS? An empirical evaluation under different diary window lengths. Applied Economics, 45(20), 29943010 .

DOI: $10.1080 / 00036846.2012 .690852$

Frazis, H., \& Stewart, J. (2012). How to think about time-use data: what inferences can we make about long-and short-run time use from time diaries? Annals of Economics and Statistic, 231-245.

Fuwa, M. (2004). Macro-level gender inequality and the division of household labor in 22 countries. American Sociological Review, 69 (12), 751-767.

Fuwa, M., \& Cohen Philip N. (2007). Housework and social policy. Social Science Research, 36, 2007, 512-530.

doi:10.1016/j.ssresearch.2006.04.005

Gammage, S. (2010). Time pressed and time poor: Unpaid household work in Guatemala. Feminist Economics, 16(3), 79-112.

DOI: $10.1080 / 13545701.2010 .498571$

Garikipati, S. (2012). Microcredit and women's empowerment: Through the lens of time-use data from rural India. Development and Change, 43(3), 719- 
750.

DOI: $10.1111 / \mathrm{j} .1467-7660.2012 .01780 . x$

Geist, C, \& Ruppanner, L. (2018). Mission impossible? New housework theories for changing families. Journal of Family Theory \& Review, 10, 242-262. DOI: $10.1111 / \mathrm{jftr} .12245$

Gershuny, J., B. and Michael B, J. (2005). Exit, voice, and suffering: Do couples adapt to changing employment patterns? Journal of Marriage and Family, 67, 656-665.

Gimenez-Nadal, J. I., \& Sevilla, A. (2012). Trends in time allocation: A crosscountry analysis. IZA DP, No. 6709.

Golden, L. (2008). Limited access: Disparities in flexible work schedules and work-at-home. J Fam Econ Iss., 29, 86-109. DOI 10.1007/s10834-0079090-7

Gough, M., \& Killewald, A. (2010). Gender, job loss, and housework: The time availability hypothesis revisited (Population Studies Center Research Report 10, 710). University of Michigan. Retrieved from https://www.psc.isr.umich.edu/pubs/pdf/rr10-710.pdf

Gough, M., \& Killewald, A. (2010). Money isn't everything: Wives' earnings and housework time. Social Science Research, 39, 987-1003. doi:10.1016/j.ssresearch.2010.08.005

Greenstein, T. N. (2000). Economic dependence, gender, and the division of labor in the home: A replication and extension. Journal of Marriage and the Family, 62(5), 322-335.

Guday Emirie. (2005). Early marriage and its effects on girls' education in rural Ethiopia: The case of Mecha Woreda in West Gojjam, North-Western Ethiopia (Doctoral Dissertation). Germany: Georg-August University of Göettingen.

Gupta, S. (2007). Autonomy, dependence, or display? The relationship between married women's earnings and housework. Journal of Marriage and Family, 69, 399-417.

Guryan, J., Hurst, E., \& Kearney, M., S. (2008). Parental Education and Parental Time with Children." Journal of Economic Perspectives, 22(3), 23-46.

Hallman, K., Quisumbing, A. R., Ruel, M., \& de la Briere, B. (2005). Mothers' work and childcare: Findings from the urban slums of Guatemala City. Economic Development and Cultural Change, 53 (4), 855-885.

Heisig, J. P. (2011). Who does more housework: Rich or poor? A comparison of 33 countries. American Sociological Review, 76(1), 74-99. DOI: $10.1177 / 0003122410396194$ 
Chalachew Getahun

Hirut Bekele Haile. (2010). Targeting married women in microfinance programmes: transforming or reinforcing gender inequalities? Evidence from Ethiopia (Doctoral Dissertation). Netherlands: Wageningen University,

Ilahi, N. (2000). The Intra-household allocation of time and tasks: What have we learnt from the empirical literature? (Working Paper Series No. 13). The World Bank Development Research Group. Retrieved from http: //www.worldbank.org/gender/prr.

Krantz-Kent, R. (2009). Measuring time spent in unpaid household work: results from the American Time Use Survey (Monthly Labor Review). US Bureau of Labor Statistics.

Lachance-Grzela, M., \& and Bouchard, G. (2010). Why do women do the lion's share of housework? A decade of research. Sex Roles, 63, 767-780. DOI 10.1007/s11199-010-9797-z

Lahiri-Dutt, K., \& Sil, P. (2014). Women's 'double day' in middle-class homes in small-town India. Contemporary South Asia, 22(4), 389-405. DOI: 10.1080/09584935.2014.979762

Lincoln, A. E. (2008). Gender, Productivity, and the marital wage premium. Journal of Marriage and Family, 70, 806-814.

Lundberg, S. and Pollak, R. A. (2003). Separate spheres bargaining and the marriage market. Journal of Political Economy, 101(6), 988-1010.

Masuda,Y. J. Fortmann, L. Gugerty, M. K., Smith-Nilson, M.,\& Cook, J. (2014). Pictorial approaches for measuring time use in rural Ethiopia. Soc Indic Res, 115(1), 467-482. doi:10.1007/s11205-012-9995-x.

McGinnity, F., \& Russell, H. (2008). Gender inequalities in time use: The distribution of caring, housework and employment among women and men in Ireland. Ireland: Brunswick Press.

Medeiros, M. Osório, R. G., \& Costa, J. (2007). Gender inequalities in allocating time to paid and unpaid work: Evidence from Bolivia (The Levy Economics Institute Working Papers, No. 495). Retrieved from http://hdl.handle.net/10419/31656

Newman, C. (2001). Gender, time use, and change: The impact of the cut flower industry in Ecuador. The World Bank Economic Review, 16 (3), 375-396. DOI: $10.1093 /$ wber/lhf006

Parkman, A., M. (2004). Bargaining over housework: The frustrating situation of secondary wage earners. The American Journal of Economics and Sociology, 63(4).

Pinto, K. M., \& Coltrane, S. (2008). Divisions of labor in Mexican origin and 
Anglo families: Structure and culture. Sex Roles, 60(7), 482-495. DOI 10.1007/s11199-008-9549-5

Ringheim K, Teller C. \& Sines E. (2009). Ethiopia at a crossroads: Demography, gender, and development. Washington D.C.: Population Reference Bureau Policy Brief.

Ringhofer, L. (2015). Time, labour, and the household: measuring "time poverty through a gender lens. Development in Practice, 25(3), 321-332. DOI: 10.1080/09614524.2015.1016867.

Robinson, B. K., \& Hunter, E. (2008). Is mom still doing it all? Reexamining depictions of family work in popular advertising. Journal of Family Issues, 29(4), 465-486. DOI: 10.1177/0192513X07310311

Singh, P., Paleti, R., Jenkins, S., \& Bhat, C. R. (2013). On modeling telecommuting behavior: Option, choice, and frequency. Transportation, 40(2), 373-396.

Solomon B., \& Kimmel J. (2009). Testing the inverseness of fertility and labor supply: The case of Ethiopia (IZA Discussion paper No. 3949). Western Michigan University and IZA.

Stewart, J. (2009). Tobit or not tobit? (IZA DP No. 4588). Bonn, IZA.

Sullivan, O., Billari, F. C., \& Altintas, E. (2014). Fathers' changing contributions to child care and domestic work in very low-fertility countries: the effect of education. Journal of Family Issues, 35(8), 1048-1065. DOI: 10.1177/0192513X14522241

Tsuya, N., O., Bumpass, L. L., and Choe, M. K., (2000). Gender, employment, and housework in Japan, South Korea, and the United States. Review of Population and Social Policy, 9, 195-220.

University of Michigan. 2008. Exactly how much housework does a husband create? Retrieved from https://news.umich.edu/exactly-how-muchhousework-does-a-husband-create/

Wessen Shiferaw. (2008). Gender-based division of labor among the Majangir community in South Western Ethiopia (M.A. Thesis). Addis Ababa University.

World Bank. (2001). Engendering development through gender equality in rights, resources, and voice. Washington D. C.: Oxford University Press. 